\title{
Authentication of a Painting by Nicolae Grigorescu Using Modern Multi-Analytical Methods
}

\author{
Petru Ovidiu Tanasa ${ }^{1}$, Ion Sandu ${ }^{2,3}{ }^{\circledR}$, Viorica Vasilache ${ }^{2}{ }^{(}$, Ioan Gabriel Sandu ${ }^{3,4, *}$, \\ Ioan Cristinel Negru ${ }^{1}$ and Andrei Victor Sandu $3,4, * \mathbb{C}$ \\ 1 Faculty of Geography and Geology, Doctoral School of Geosciences, Alexandru Ioan Cuza University of Iasi, \\ 20A Carol I St., Corp B, 700506 Iasi, Romania; ovidiu_cml2000@yahoo.com (P.O.T.); \\ negru.cristi@gmail.com (I.C.N.) \\ 2 Institute of Interdisciplinary Research, Alexandru Ioan Cuza University of Iasi, ARHEOINVEST Center, \\ 11 Carol I St., 700506 Iasi, Romania; ion.sandu@uaic.ro (I.S.); viorica_18v@yahoo.com (V.V.) \\ 3 Romanian Inventors Forum, 3 Sf. Petru Movila St., 700089 Iasi, Romania \\ 4 Faculty of Material Science and Engineering, Gheorghe Asachi Technical University of Iași, \\ 41 D. Mangeron St., 700050 Iasi, Romania \\ * Correspondence: gisandu@yahoo.com (I.G.S.); sav@tuiasi.ro (A.V.S.)
}

Received: 26 April 2020; Accepted: 19 May 2020; Published: 21 May 2020

\section{Featured Application: Authentication of Cultural Heritage Works.}

\begin{abstract}
The paper presents the expertise of authenticating a painting by Nicolae Grigorescu through the involvement of multi-analytical techniques, in order to identify and evaluate some archaeometric and chemometric characteristics of the pictorial materials and of the support, used in determining the age. The painting is made with oil colors on pressed cardboard, with preparation based on chalk powder and animal glue. The painting presents two elements as being counterfeit, which have attracted suspicions, namely the signature of the author (presenting a semi-transparent covering veil), and, on the back, a writing of dating, performed by a very controversial art historian. The investigation was carried out by direct analysis with magnification devices, in reflected UV (ultraviolet), VIS (visible), and NIR (near- infrared) light, and by OM, SEM-EDX, and $\mu$-FTIR. The results showed that the painting is authentic and belongs to Nicolae Grigorescu, and the dating established previously by Amelia Pavel through the writing on the back is certain.
\end{abstract}

Keywords: oil painting; Nicolae Grigorescu; authentication; archaeometry; chemometrics; OM; static and dynamic reflection; SEM-EDX; $\mu$-FTIR

\section{Introduction}

It is known that paintings based on talent, creativity, and craftsmanship, have become in time cultural heritage goods, true historical testimonies. These, in addition to the heritage elements highlighted at the elaboration (author/workshop, the artistic technique, the technology of the artwork, and materials) and later (age, the historical patina, value, owner/custodian, transfer, and itinerary) [1,2], take over certain heritage functions, over time, which make them invaluable and undeniable. These patrimonial functions are aesthetic-artistic, historical-documentary, technical-scientific, socio-economic/urban, and spiritual $[3,4]$.

Authentication of a painting does not only mean dating and establishing the author, workshop, or school, but much more: determining the route from conception to collection/museum (historical contexts) and structural-functional evolution (modification of the physical, aesthetic, and conceptual state). To these are added a series of attributes related to the area where the artwork was created, the area of use, 
of belonging (owner/custodian/gallery/museum), itineraries, and heritage value (share of stock or catalog), etc. [5-11].

In the complex activity of authenticating an unknown painting, the historian or art critic, the so-called traditional expert, is helpless today without collaboration with technical-scientific experts from related fields (chemistry, physics, biology, geology, archeology, anthropology, forensic science, etc.) [1,5].

In addition to the aesthetic-artistic expertise, in authentication it is mandatory to determine the archaeometric characteristics or to evaluate the chemometric ones, with archaeometric value, used for dating or author establishment. Initially, the conservation status expertise will be carried out by analyzing the evolutionary effects of physical state deterioration of the structural-functional elements and of degradation of the chemical nature of the component materials. These allow the establishment of the two very important groups of attributes: the patrimonial elements or characteristics and patrimonial functions, which often coexist in determining the authenticity [1,11-13].

At present we are also witnessing an atypical phenomenon. Some public or private collections detain fake artworks or archaeological pieces, part of them without acknowledging this, for several subjective reasons. Moreover, fakes wear the defining features of a particular style, which reproduces the faithful characteristics of a "genuine original", easily succeeding in convincing buyers, art dealers, or collectors [14-16].

Often, the owner of an unknown or uncertain painting, even if it is signed and dated, he or she will want a sure attestation of the date and the author. In Romania there are many examples of attributions made by art historians specialized on a certain artist or type of artifact. Among them, the historian Amelia Pavel, who performed the aesthetic-artistic expertise, and, in conjunction with the plastic and graphoscopic analysis, a large series of paintings by some Romanian or European authors, is much discussed. Some critics support her as an established expert, while others say she is controversial and has been superficial in some authentications $[15,16]$.

In this paper, two important aspects were pursued: establishing the authenticity of a painting by the Romanian painter Nicolae Grigorescu by determining some archaeometric and chemometric characteristics, with archaeometric value, implying a modern system of multi-analytical techniques, together with the validation of the author's signature and the previous evaluation expertise performed by Amelia Pavel, both with the same purpose of dating and establishing the author.

\section{Experimental}

In the analysis a painting of Nicolae Grigorescu (b. 15.05.1838, Pitaru/Dâmbovița-d. 21.07.1907, Câmpina/Prahova) was taken, for performing the authentication expertise and for validating the dating and attribution writing, on the back, signed by the art historian Amelia Pavel from Bucharest. The painting was investigated at the request of a collector, who purchased it from the free antique market in Bucharest. In addition to establishing the authenticity of the painting, the owner also requested the verification of the attribution of the inscription on the back, signed by Amelia Pavel on September 28, 1999, by which the work titled "Flowers of apple", was considered to be the work of the painter Nicolae Grigorescu.

\subsection{Description of the Painting. Comparison with Other Works and Specimens of Signatures Belonging to the Author}

The painting represents a static nature, was made with thick paste with a wide brush, on cardboard, in oil colors. The subject is a large pot of burnt clay, glazed in the upper half in green, with branches of apple blossoms (Figure 1). The painting has a massive frame, made of fir, with carved, gilded, and varnished ornamental wands, applied on the inner edge, towards the painting and at the center of the frame top (Figure 1a). The frame is patinated with a transparent varnish, with dirt deposits in the profile of the ornament. The support and the frame of the painting have a rectangular shape. 


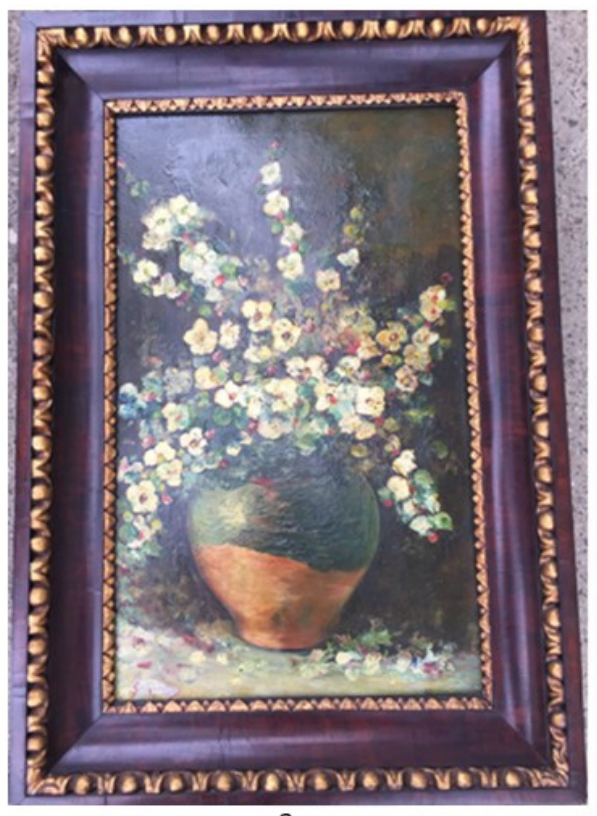

a

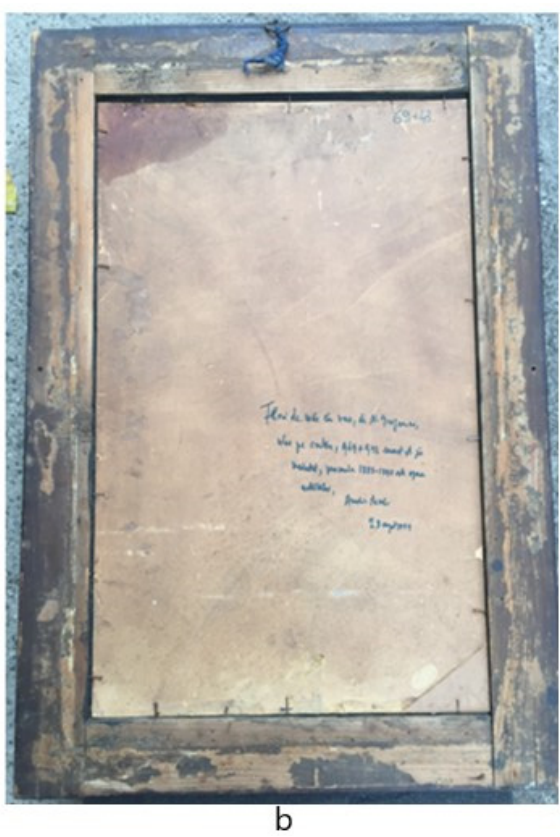

b

Figure 1. The painting "Flowers of apple", attributed to the painter Nicolae Grigorescu. (period 1888-1890): (a) front; (b) back.

The dimensions of the painting are $690.0 \times 430.0 \times 3.13 \mathrm{~mm}$ (dimensions of the cardboard support, without frame-Figure 2).

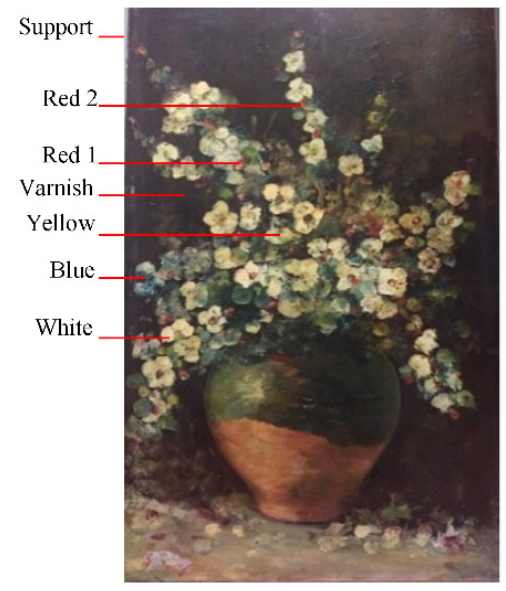

Figure 2. The painting disassembled for dimensional measurements. Sampling areas.

The author's signature is positioned in the lower left corner. This is in English red color, on a white background, made with a spatula in order to facilitate the writing of the signature, over which a semi-transparent white veil with partial coverage has been applied (Figure 3). During the visual examination of the area aroused suspicion that the signature may have been tampered with.

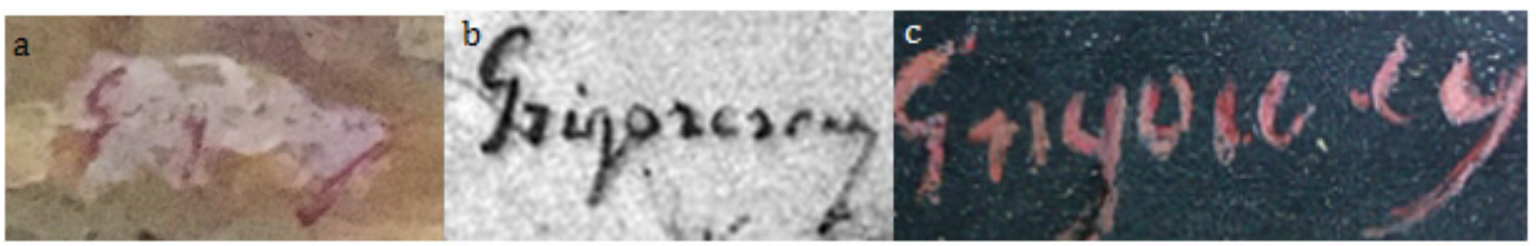

Figure 3. Author's signature on the painting taken in the analysis (a) and on two paintings from state collections $(\mathbf{b}, \mathbf{c})$. 
The support is made of pressed cardboard, $3.13 \mathrm{~mm}$ thick and carries an ageing patina. On the back side, at the center-right towards the bottom corner, is the authentication writing, in a black ink with a bluish tint, signed by Amelia Pavel: "Flowers of apple in the pot, by N. Grigorescu, oil on cardboard, $0.69 \times 0.43$, signed lower left, undated, period 1888-1890, is the work of the artist, Amelia Pavel, September 28, 1999" (Figure 1b).

Amelia Pavel (b. 07.11.1915, Bucharest-d. 21.12.2003, Bucharest), was known as an art critic and historian, essayist, and memorialist, member of the Association of Art Critics (since 1960).

The critic Pavel Şuşară (b. 29.12.1952, Bănia/Caraș Severin) recognizes that Amelia Pavel "is a good specialist of European and universal art, with a solid literary, philosophical and aesthetic culture, ... deeply involved in the Romanian art, especially in the interwar one ..., ... has created a way to evaluate and to judge generously, without voluntarism and without the slightest prejudice ..." [17-19]. Recently, during a telephone conversation of the authors with Pavel Susara, it was found that not all attribution writings are true in evaluations, having a high degree of subjectivity related to the owner, or were superficial in documentation and analysis.

Regarding anamnesis (data on origin and route): the owner did not provide any other data, except that the painting was purchased in 2018 and is currently kept in the family, displayed on the wall in the living room.

The motif of apple blossoms or of flowers in burnt clay pots was very often approached by Grigorescu. There are many paintings with these themes. Of these, three were taken as comparison system and are shown in Figure 4. The paintings presented are very close in style of approach, materials and artistic technique.
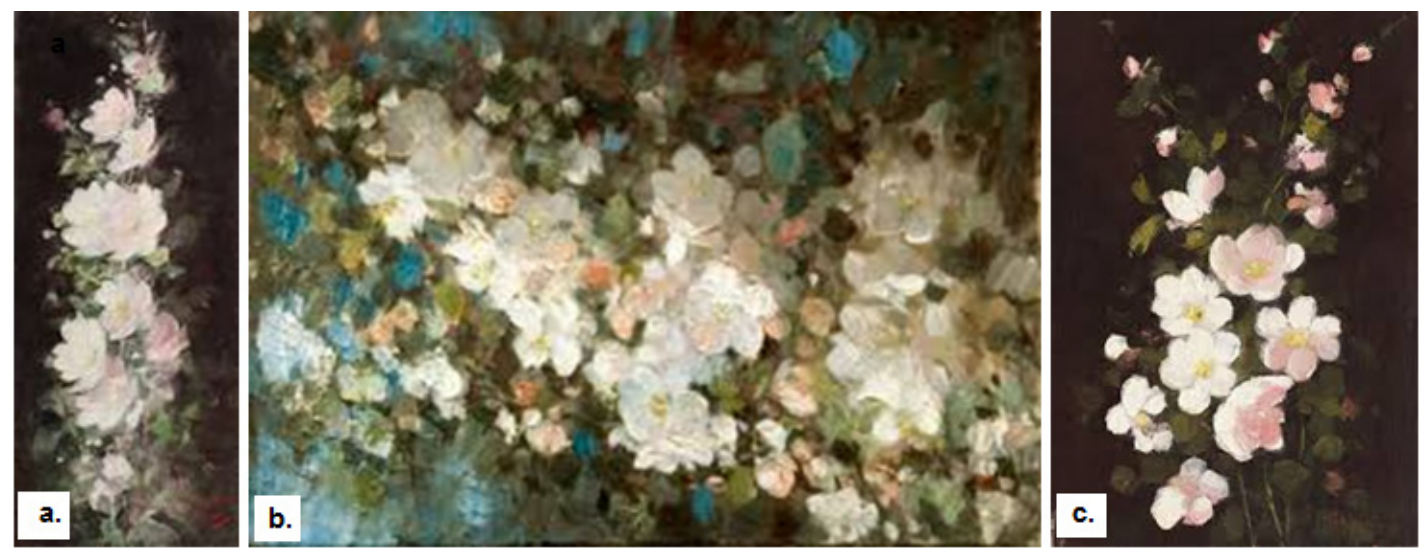

Figure 4. Paintings depicting apple flowers, painted by Nicolae Grigorescu, from three private collections: (a). "Apple flowers" (1863-1865), oil on wood (310 × $135 \mathrm{~mm})$; (b) "Apple flowers" (1903-1904), oil on wood (235 × 140 mm); (c) "Apple flowers" (1867-1869), oil on cardboard (230× 160 mm).

\subsection{Sample Management and Processing}

In order to determine the nature of the component materials (pictorial layers/varnish, polychrome, preparation, and support) and their state of preservation, as well as to identify some archaeometric characteristics, a series of samples were taken, especially for painting materials: varnish, color (indexed C1 ... $\mathrm{Ci}, \mathrm{C}=$ color; $\mathrm{i}=$ area analyzed), and support (S). In the determinations, the fractal material samples were used as such or summarily processed by division.

As at the elaboration of the artwork the pictorial materials were applied in a thick layer with a wide brush, the samples were taken with a scalpel from areas with dynamic cracks (partially detached scaly structures). Eight representative samples of color were selected. The state of preservation of both the varnish and the paint layer (pigment + binder based on boiled linseed oil), required a careful sampling as they were brittle and strongly fragile. 


\subsection{Methods, Techniques, and Devices Involved in the Expertise}

Along with the visual analysis with magnifying instruments (manual magnifiers) and stereo microscope (STEREO MX4, 10X-220X), a series of high-resolution mobile devices and instruments were used, of which we mention [1,20-28]:

- Forensic magnifier, with USB port, HS525A series, made by SZZCX Company, China, 2016 model, 30-50× magnification with UVA ( $365 \mathrm{~nm})$, UVC ( $254 \mathrm{~nm})$, Infrared (IR $850 \mathrm{~nm}, 940 \mathrm{~nm})$, White-blue $(470 \mathrm{~nm})$, white-green $(550 \mathrm{~nm})$, Laser $(980 \mathrm{~nm})$. View area: $12-9 \mathrm{~mm}$.

- Digital microscope with USB power supply, 1.3 MP (2.0 MP interpolated), model Discovery DX-1, made by Veho, China. Manual focus from 10 to $500 \mathrm{~mm}$, frame rate: $\max 30 \mathrm{f} / \mathrm{s}$ under $600 \mathrm{~lx}$ brightness, eight white LEDs with adjustable lighting. Magnification rate from $20 \times$ to $200 \times$, AVI video format.

- Portable UV lighting device, with LED, G5, 4W UV. Model no. EGHHUV4, made by Voila, China.

Additionally, for the determination of chemical and physical-structural characteristics, scanning electron microscopy coupled with X-ray spectrometry (SEM-EDX), high resolution optical microscopy, and $\mu$-FT-IR spectrophotometry were used.

SEM-EDX Microscopy. The analysis used a scanning electron microscope (SEM) model VEGA II LSH, produced by TESCAN Czech company, coupled with an EDX detector type QUANTAX QX2, produced by BRUKER/ROENTEC Germany. The microscope, fully computer controlled, has a tungsten filament electron gun, which can achieve a resolution of $3 \mathrm{~nm}$ at $30 \mathrm{kV}$, with magnification power between $30 \times$ and 1,000,000 $\times$ in "resolution" operating mode, acceleration voltage between $200 \mathrm{~V}$ and $30 \mathrm{kV}$, scan speed between $200 \mathrm{~ns}$ and $10 \mathrm{~ms}$ per pixel. The working pressure is less than $1 \times 10^{-2} \mathrm{~Pa}$. The image obtained can be made up of secondary electrons (SE) or back-scattered electrons (BSE). Quantax QX2 is an EDX detector used for qualitative and quantitative micro-analysis. The EDX detector is of the third generation, type $\mathrm{X}$-flash, which does not require liquid nitrogen cooling and is about 10 times faster than conventional $\mathrm{Si}(\mathrm{Li})$ detectors. The technique, together with the visualization of the microphotography, allows the image to be reproduced with the mapping (arrangement) of the atoms on the investigated surface. Based on the EDX spectrum, the determination of the elemental composition (in gravimetric or molar percentages) of a microstructure or of a selected area, was made.

$\mu$-FT-IR Spectrometry. For $\mu$-FTIR analysis an FT-IR spectrophotometer coupled to a Hyperion 1000 microscope was used, both produced by Bruker Optik, Germany. The FT-IR spectrophotometer is a Tensor 27 model, which is foremost suitable for measurements in the near IR. The standard detector is DLaTGS, which covers the spectral domain $7500-370 \mathrm{~cm}^{-1}$, and works at room temperature. The standard resolution is $4 \mathrm{~cm}^{-1}$, but it can also reach $1 \mathrm{~cm}^{-1}$. Tensor 27 is fitted with a He-Ne laser, which emits at $633 \mathrm{~nm}$ and a power of $1 \mathrm{~mW}$, presenting a Rocksolid alignment of the interferometer. The signal/noise ratio of this spectrophotometer is very good. Tensor 27 is fully controlled through the Opus software. The Hyperion 1000 microscope is an accessory that can be coupled with almost any FT-IR spectrophotometer produced by Bruker. For fully nondestructive readings, the Tensor 27 spectrophotometer is coupled to the Hyperion 1000 microscope; usually, for solid samples, the work is done in reflectance mode. The software used is Opus/Video, for the acquisitioning of interactive video data. It is possible to work both in transmission and reflection modes. The detector is an MCT type, cooled with liquid nitrogen $\left(-196^{\circ} \mathrm{C}\right)$. The spectral domain in which the work was carried out was $600-4000 \mathrm{~cm}^{-1}$. The microscope is fitted with a $\times 15$ lens.

Optical microscopy. In optical microscopy analyses, a Zeiss Imager a1M microscope is used, which has an AXIOCAM camera and specialized software attached. The samples were analyzed at 50-200× magnification in a dark or bright field. 


\section{Results and Discussions}

\subsection{Aesthetic-Artistic Analysis of the Painting}

The painting was made on a pressed cardboard support with a preparation based on animal glue and chalk powder, in a thin film. The technique is in oil colors, applied with the wide brush or the thin blade of the palette knife, with areas in thick layer or stretched in thin layer. Thereby, the flowers were painted with the wide brush in a thick layer, in white colors, with the stamens and the pistil in yellow and red. The background was painted in a burnt shadow, and the table in a mixture of sepia green, very light, imprinted with burnt shades and ocher, and fallen leaves alongside petals, for chromatic balance. On the table, in the center, is a large pot of burnt clay, with green glaze, in which there is a bouquet of apple branches with fresh flowers. The iconographic perspective and the lights are rendered by Grigorescu's unmistakable style [26,27].

Three central areas were analyzed in white light and one in UV light, in which no counterfeiting interventions are shown (Figure 5).

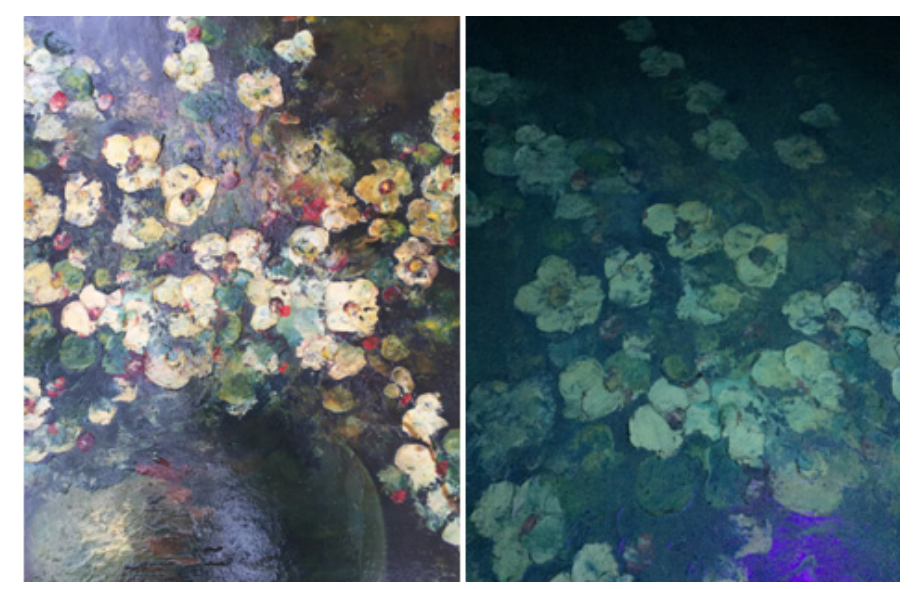

Figure 5. Analysis in white light (left) and UV (right) of two central areas of painting, which demonstrates the lack of falsification interventions.

\subsection{Signature Analysis}

Particular attention was paid to investigating the area with the author's signature. Initially, this was analyzed by UV (365 nm), VIS (430-680 nm), and IR (850 nm) reflectography, in which a non-uniform route of the signature was highlighted, which from the graphoscopic point of view corresponds to the specific characters of the author for the period 1888-1890 (which also includes the period established by Amelia Pavel).

Figure 6 shows a fragment from the area of the signature, analyzed at the binocular stereomicroscope in white light, respectively, the image of the entire area of the signature in UV reflectography.

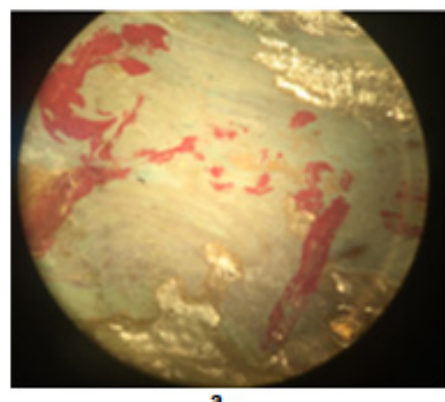

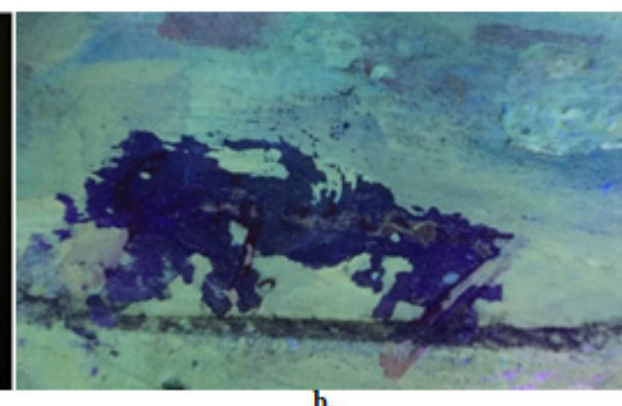

b.

Figure 6. Painter's signature: (a) microphotography of a fragment by binocular stereomicroscope; (b) UV reflectography image of the entire area. 
Figure 7 shows a detailed analysis, using Forensic magnifier HS525A technique, of areas with different signature characters, under visible and white-green $(550 \mathrm{~nm})$ light, dynamically reflected from two specific graphoscopic areas of the signatures (letters $G$ and g), to highlight the touch of paint and the writing traces.
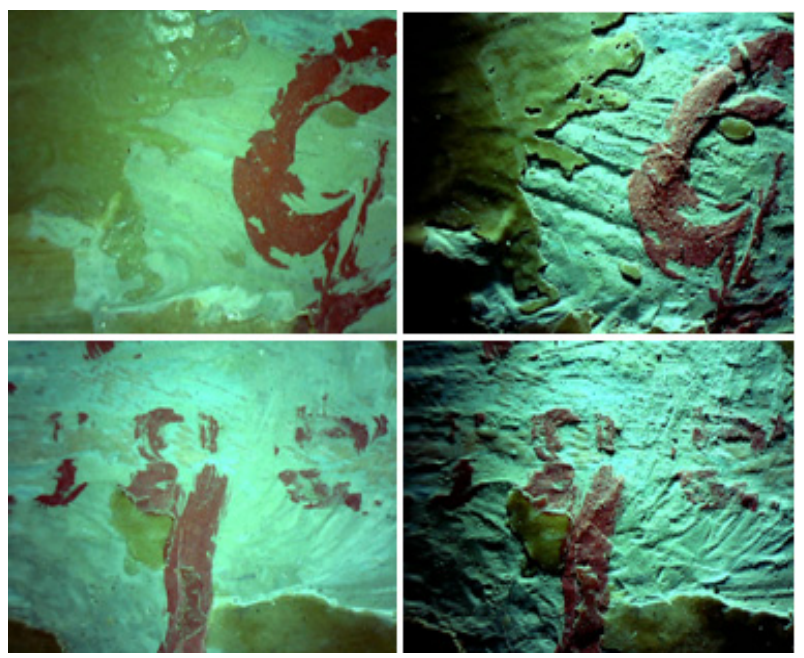

Figure 7. Areas with signature characters, in visible and white-green light dynamically reflected from two analysis areas.

Furthermore, with the same device were analyzed under the three reflected lights: white-green $(550 \mathrm{~nm}), \mathrm{UV}(365 \mathrm{~nm})$, and IR $(850 \mathrm{~nm})$, along with the two areas of the signature (letters $\mathrm{G}$ and $\mathrm{g})$, an adjacent area, in order to remove any suspicion of forgery upon signature (Figure 8 ).
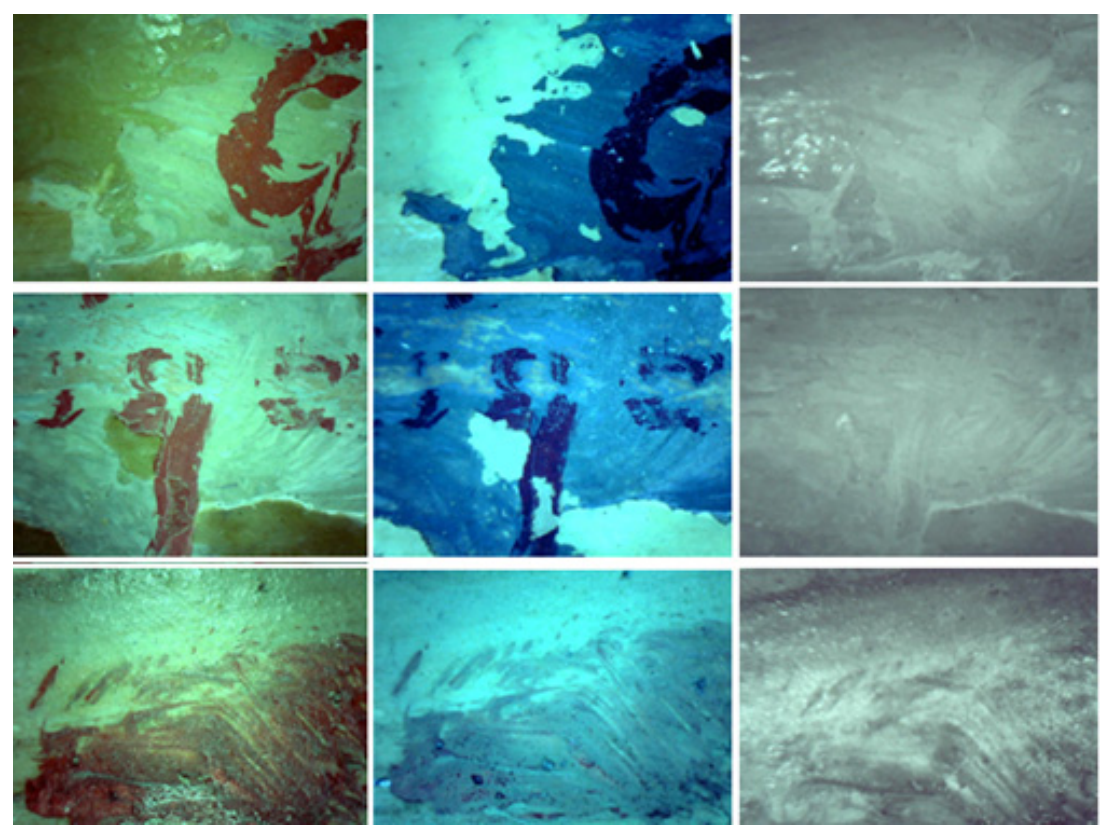

Figure 8. Analysis in the three reflected lights: white-green (550 nm), UV (365 nm), and IR (850 nm) of some areas with signature characters in Figure 7 and of other area where false writing is suspected.

The analysis of the nine images in Figure 8 does not highlight counterfeiting interventions.

Figure 9 shows Amelia Pavel's authentication writing on the back of the painting, in the three reflected lights (white-green, UV, and IR), which is not legible, most likely due to the use of a special ink which does not interact reflectographically with the three lights. This writing can only be seen in the visible (D50). 

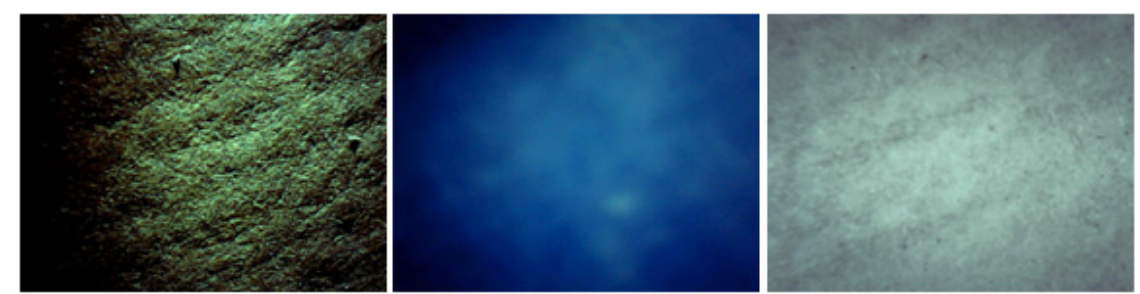

Figure 9. Analysis of Amelia Pavel's writing in the three reflected lights: white-green (550 $\mathrm{nm})$, UV (365 nm), and IR (850 nm).

Figure 10 comparatively shows the graphoscopic analysis in direct white-green light and in two reflected lights: white-green $(550 \mathrm{~nm})$ and UV $(365 \mathrm{~nm})$, two fragments from the signature of Amelia Pavel, which corresponds to the signed period. In Figure 11, by comparing the alignment of the main representative characters of Amelia Pavel's writing and signature, there is similarity with other signatures and writings of the author (autographs of book author).
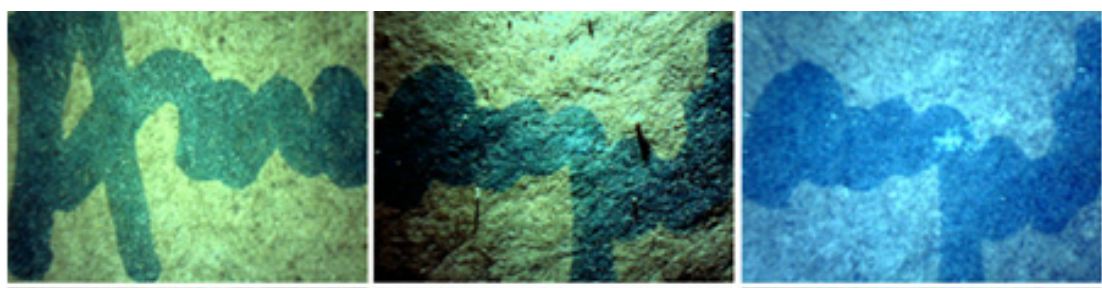

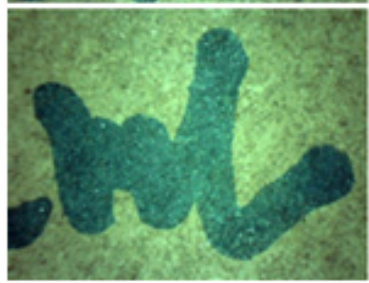

a.

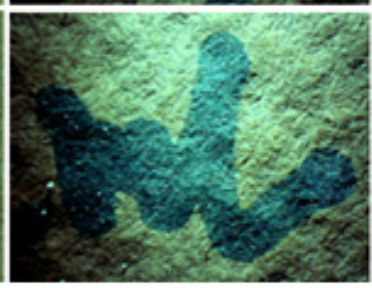

b.

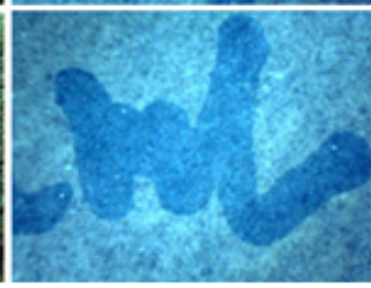

c.

Figure 10. Fragments from Amelia Pavel's signature in direct white-green light (a), compared with two reflected lights beams: white-green (b) and UV (c).

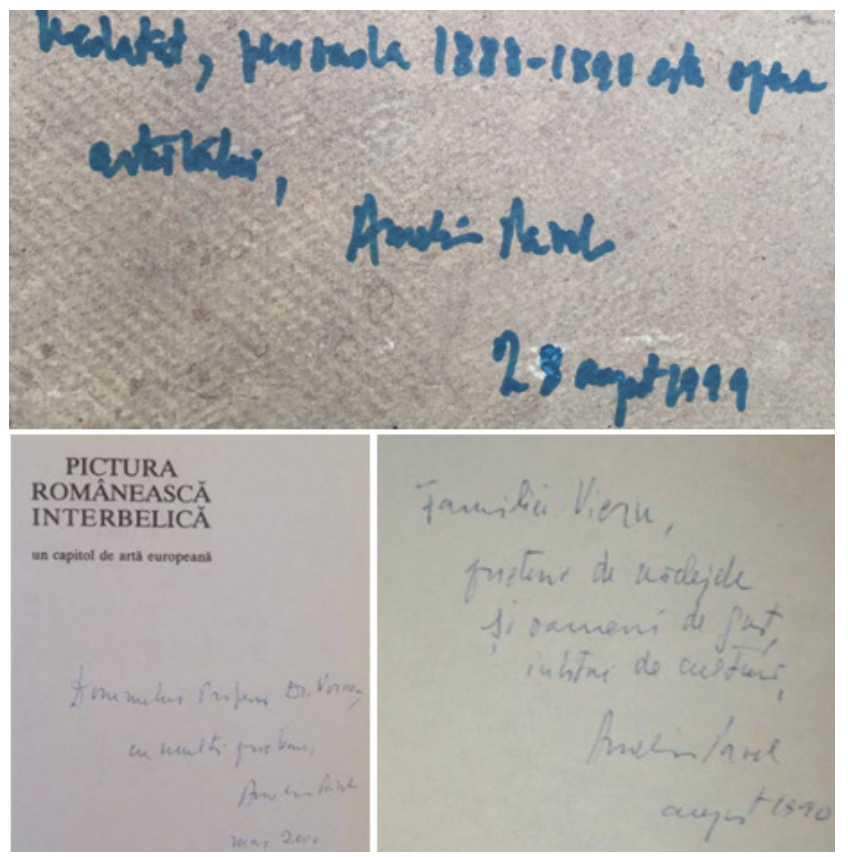

Figure 11. Comparative analysis of Amelia Pavel's signature. 


\subsection{Conservation Status Examination by Direct Methods}

The painting surface was re-varnished with a colorless varnish, slightly yellow, during the interwar period.

It presents insignificant lack of pictorial material, support, and polychromy in the framed areas (below the corner of the frame). There are no visible ageing cracks, except in restricted areas of white flower petals. There are also lacunae in painting material in several central areas at the flower petals. The nails used to fix the bracket in the frame appear to be original, and the presence of irises denotes the installation and repeated disassembly of the painting in the frame.

Figure 12 shows the images of areas with ageing cracks and other superficial deteriorations of the pictorial layers, analyzed in the three reflected lights: in white-green, UV, and IR light, which highlight cracks and age changes, without counterfeiting interventions.
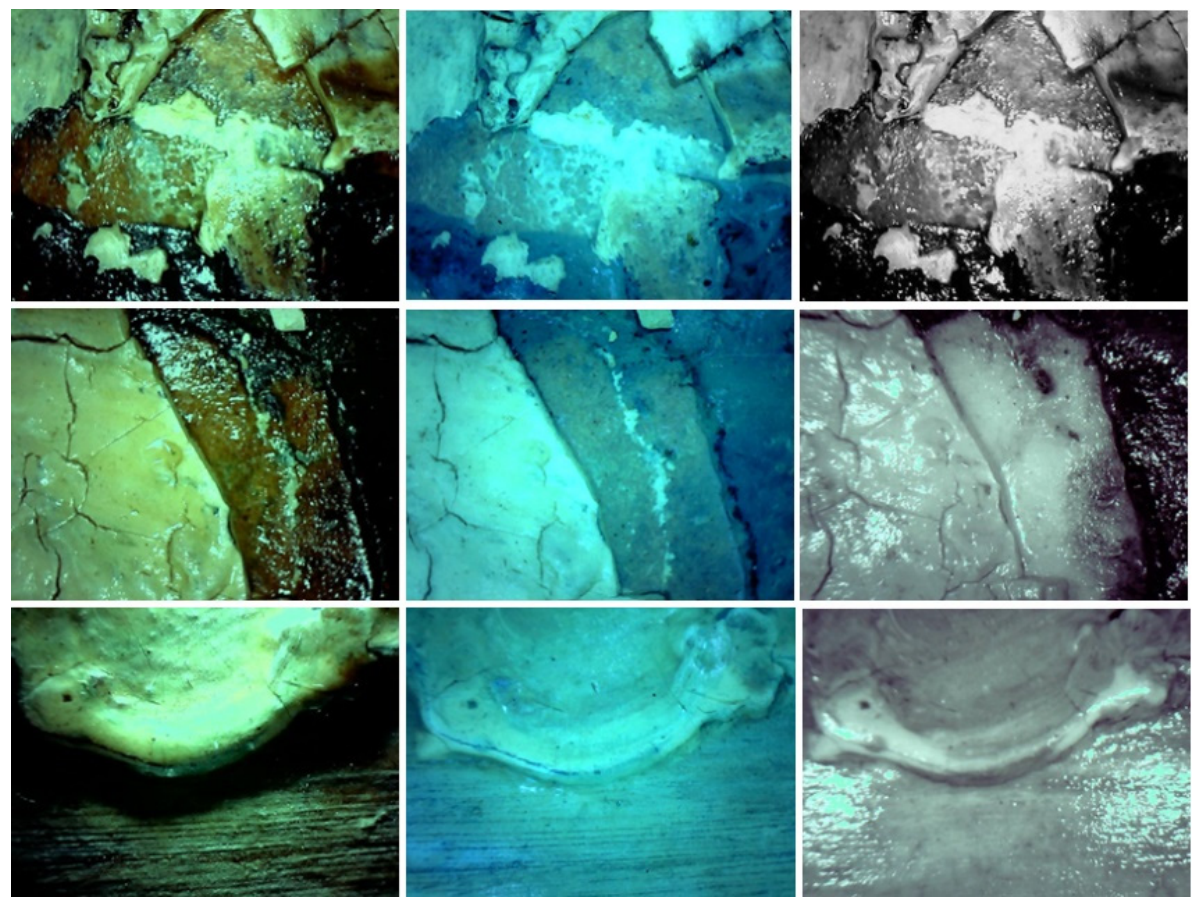

Figure 12. Images of areas with ageing cracks and other superficial deteriorations of the pictorial layers, analyzed in the three reflected lights: white-green $(550 \mathrm{~nm}), \mathrm{UV}(365 \mathrm{~nm})$, and IR $(850 \mathrm{~nm})$, using Forensic magnifier at $30 \times$.

Framing interventions are visible, and the back support has many areas with torn or missing cardboard (in the area of fixing nails).

Through UV and visible reflectography, re-varnishing interventions are observed. Instead, no repainting interventions are observed. There are no falsification interventions (structural and chromatic reintegration of the painting layer and framing). At stereomicroscopy, ageing cracks are visible at the level of the flower petals and no interventions have been revealed after the execution.

The frame shows an inactive xylophagic attack (Figure 13) and the fastening ring is original (Figure 14). 

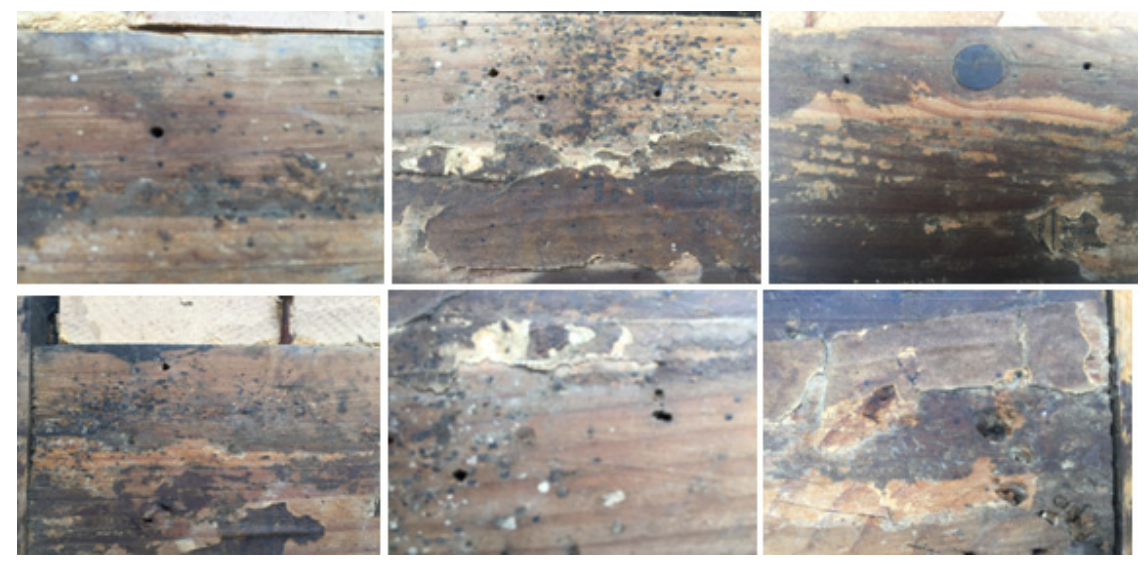

Figure 13. Flight galleries of xylophagous insects and other deterioration and degradation of back of the frame.

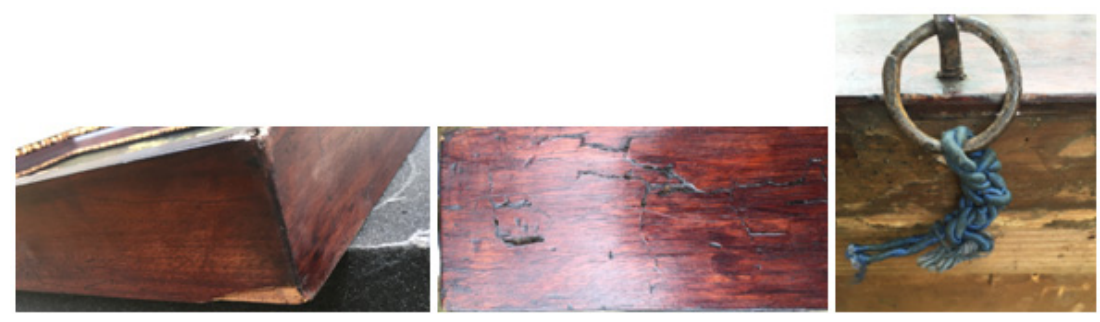

Figure 14. Fixing ring of the painting.

\subsection{Analysis of Painting Materials}

Grigorescu used a wide palette of oil colors, some used as such (unmixed), others elaborated on the panel or directly on the easel. Among the pictorial materials often used, we mention:

- boiled linseed oil, rosin based alcoholic varnishes, and other commercial resins for varnish or for mechanical and climatic protection film, also with aesthetic role;

- as pigments: zinc white, ultramarine earth colors (blue, red) or other colored earths (yellow, green, brown etc.), burnt shade, ivory black, chrome yellow, chrome green, prussian blue, english red, vermillion, green China, green Veronese, etc.

- for preparation: chalk powder and gypsum, and as a binder: boiled linseed oil, animal glue, and egg (mixture).

a. Nature of painting materials and their state of preservation

According to the data in Figure 12, a series of areas with ageing cracks and other superficial degradations of the pictorial layers are presented, analyzed in the three reflected lights: white-green, UV, and IR, which clearly highlights destructions and alterations caused by age, without interventions of forgery. The texture of the painting and of the cracks is legible with the naked eye or by using magnifying instruments. There are no highlighted interventions to consolidate or reintegrate the polychrome, but only interventions to restore the aesthetics of the painting (revarnishing).

The sampling was done by selecting the areas with mobile cracks, from where some representative samples were taken for the main pictorial materials used by the painter.

By analyzing some components of the pictorial materials using the optical microscope (OM) in dark field by a magnification of $50 \times$ and $100 \times$ (Figure 15), it is highlighted the mode and degree of elaboration of the color layer when creating the work (polychrome combination systems and stratigraphic arrangement and arrangement of color areas and varnish). Additionally, attention was paid to surface morphology (texture and microtopography) and fractal microstratigraphy, highlighting the shapes and ordering of pigment granules and cellulosic fibers of the support, followed by appreciation of their degree of alteration. The microstratigraphic structures in the fractal allowed to 
highlight the arrangement and the depth of the archaeometric characteristics. Based on data on the chemical composition of pictorial materials and support, a series of chemometric characteristics with archaeometric value were developed (atomic composition ratios, degree of penetration of the varnish in the volume phase of polychromes, and vice versa, depth of porosity and alteration of the pictorial materials). The four colors analyzed showed good chromatic and microstructural stability, as such or in summative systems (color mixture).

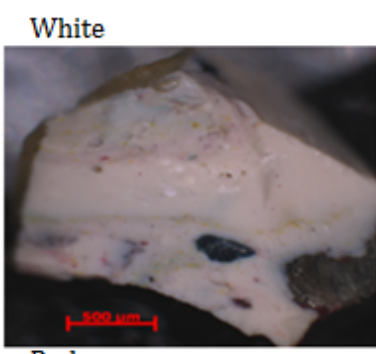

Red

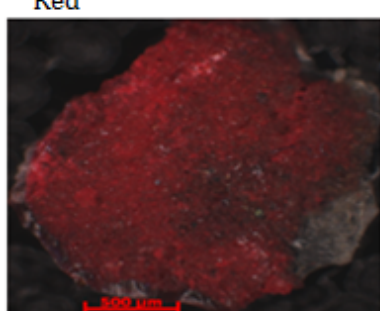

Varnish or protective film

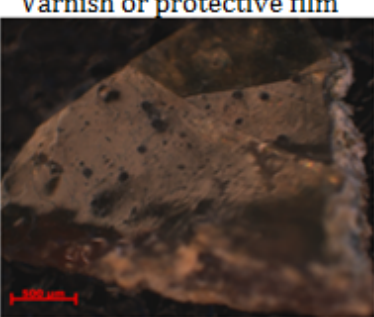

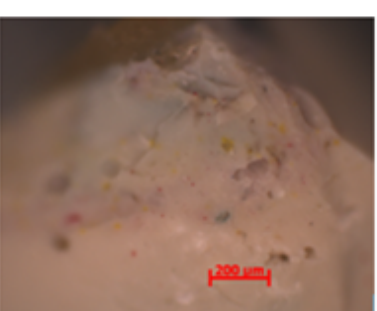
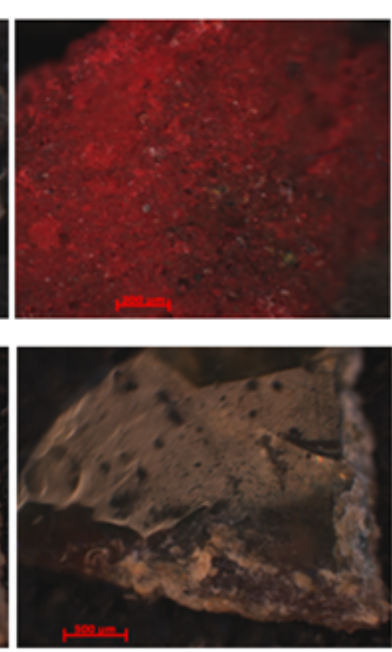

Blue

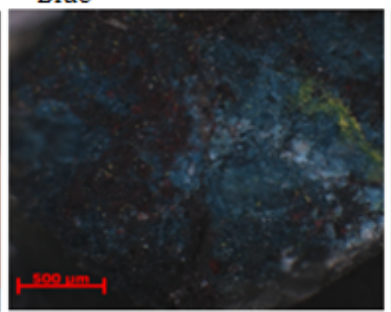

Yellow
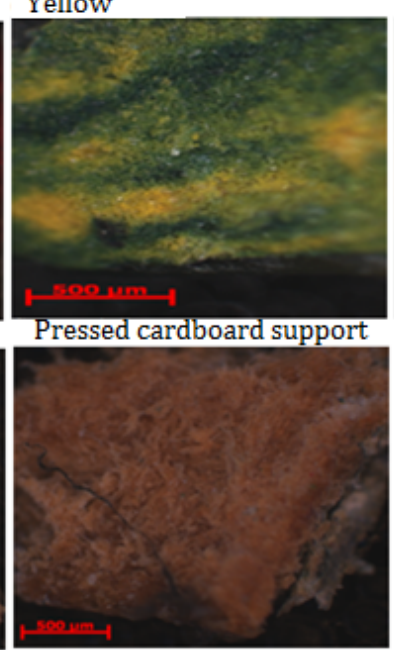
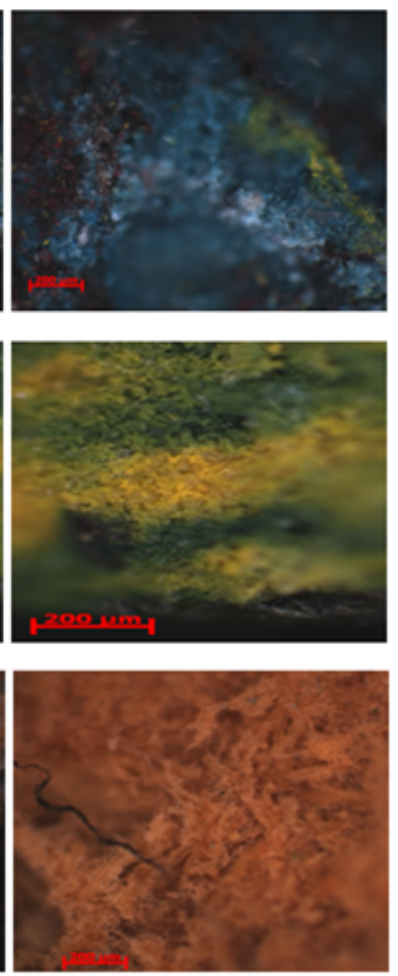

Figure 15. OM microphotographs of some components of the painting materials $(50 \times$ and $100 \times)$.

By corroborating the data by optical microscopy with those obtained by SEM-EDX and $\mu$-FTIR, a detailing is allowed, with a clear highlighting of the nature of the materials, their state of preservation, and the identification of the main archaeometric and chemometric characteristics, with archaeometric value, which allow a more precise determination of the period in which the work of art was created and the determination of the authenticity of the painting, as belonging to Nicolae Grigorescu.

Thus, the following aspects are highlighted very clearly, using the scanning electron microscope (SEM) coupled with EDX, and by $\mu$-FTIR spectrophotometry [26-30]:

- $\quad$ the manner and degree of elaboration of the colors when creating the work by the painter;

- polychrome combination systems and their stratigraphic arrangement;

- $\quad$ arrangement of the areas of varnish and dirt fouling on colors;

- $\quad$ the depth of the presence of archaeometric and chemometric characteristics, with archaeometric value (the degree of their penetration in the volume phase of the analyzed materials);

- the morphology of the surfaces, with the highlighting of the iridescence and texture, and the microtopography (alveolations, lacunae, scabs/scales, cracks and rises in the roof);

- the shape and arrangement of the pigment granules and cellulose fibers of the support;

- $\quad$ the rate of alteration of the pressed cardboard support, etc.

Figure 16 and Table 1 show the data obtained through SEM-EDX for a series of colors, varnish, and support. 


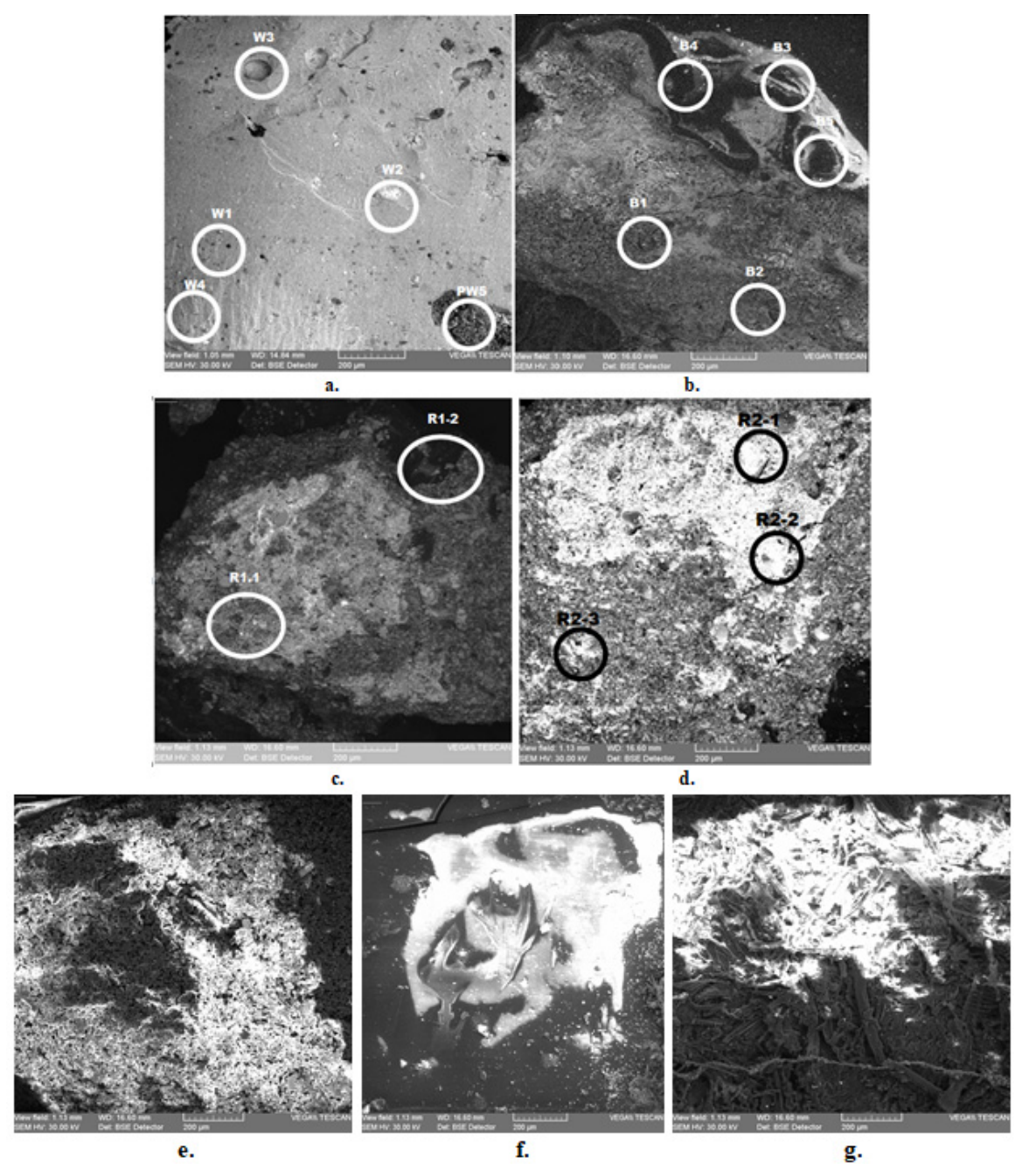

Figure 16. SEM microphotographs of some painting materials and support, analyzed in BSE: (a) samples of white color, zonal analyzed surfaces (W1-W5); (b) samples of blue color, entire analyzed surface (B0), and zonal analyzed surfaces (B1-B5); (c) samples of red 1 color, zonal analyzed surfaces (R1.1 and R1.2); (d) samples of red 2 color, zonal analyzed surfaces (R2.1, R2.2, and R2.3); (e) sample of yellow color (entire analyzed surface); (f) sample of varnish (entire analyzed surface); (g) sample of support (entire analyzed surface).

From the analysis of the texture and granulometry by SEM and of the elemental composition EDX in the sample from the white paint layer, in five analysis areas (samples W1-W5), the ZnO pigment was identified, poorly dispersed in other pigments. It had, together with a void type destruction selected in the internal structure unaffected by the environmental factors (sample W3), a porous structure of the surface layer, affected by the environmental factors (sample W4). The latter represents an archaeometric characteristic given by porosity, which gradually increases from the inside to the surface, by $250 \mu \mathrm{m}$. Additionally, the W5 sample showed an important archaeometric feature related to the surface structure with fouled dirt penetrated in the volume phase on $150 \mu \mathrm{m}$. All five areas of the white sample contain zinc oxide white pigment, poorly mixed with calcium carbonate (chalk powder- $\mathrm{CaCO}_{3}$ ) and gypsum $\left(\mathrm{CaSO}_{4}\right)$, coming from the preparation. Aluminum oxide $\left(\mathrm{Al}_{2} \mathrm{O}_{3}\right)$ from the preparation and cardboard was identified in sample W1. Sample W2 is the weakest impurified with the two fillers materials for preparation, being considered in this archaeometric evaluation as a reference sample, and zone W5 contains traces of potassium and barium aluminosilicate from contamination with atmospheric dust, fouled in varnish, with superficial penetration. This represents an archaeometric characteristic that 
differentiates this area from the first four and is given by the reduced carbon composition and increased in oxygen, due to the oxidative processes of fouling.

Table 1. Elemental composition of colors, varnish, and substrate.

\begin{tabular}{|c|c|c|c|c|c|c|c|c|c|c|c|c|c|c|c|c|}
\hline \multirow{2}{*}{\multicolumn{2}{|c|}{$\begin{array}{c}\text { Sample/ } \\
\text { Area }\end{array}$}} & \multicolumn{15}{|c|}{ Atomic Percentage Concentration (\%) } \\
\hline & & Si & Al & Mg & $\mathrm{Ca}$ & $\mathrm{Ba}$ & $\mathrm{Na}$ & $\mathbf{K}$ & $\mathrm{Zn}$ & $\mathbf{P b}$ & $\mathrm{Fe}$ & $\mathrm{Cr}$ & $\mathrm{C}$ & $\mathbf{O}$ & $\mathbf{S}$ & $\mathrm{Cl}$ \\
\hline \multirow{5}{*}{ W } & W1 & - & 0.33 & - & 0.19 & - & - & - & 18.28 & - & - & - & 20.64 & 60.28 & 0.29 & - \\
\hline & W2 & - & - & - & 0.54 & - & - & - & 23.34 & - & - & - & 16.39 & 58.87 & 0.87 & - \\
\hline & W3 & - & - & - & 0.35 & - & - & - & 18.36 & - & - & - & 23.38 & 57.31 & 0.60 & - \\
\hline & W4 & - & - & - & 0.54 & - & - & - & 31.25 & - & - & - & - & 67.76 & 0.46 & - \\
\hline & W5 & 0.63 & 0.52 & - & 4.23 & 0.39 & - & 1.58 & 2.88 & - & - & - & 11.29 & 70.80 & 7.67 & - \\
\hline \multirow{6}{*}{ B } & B0 & 0.87 & 0.74 & 0.38 & 5.04 & 0.49 & - & - & 0.58 & - & - & - & 11.02 & 73.45 & 7.44 & - \\
\hline & B1 & 0.29 & 2.08 & - & 3.25 & - & - & 0.52 & 1.29 & 0.47 & 1.04 & 0.31 & 18.73 & 57.80 & 4.10 & - \\
\hline & B2 & 0.13 & 1.75 & - & 4.35 & - & 0.01 & 1.02 & 6.59 & 0.49 & 1.81 & 0.23 & 16.58 & 62.07 & 4.95 & - \\
\hline & B3 & 1.95 & 1.52 & - & 0.22 & - & 4.52 & 0.17 & - & - & - & - & 31.30 & 59.57 & 0.46 & 0.29 \\
\hline & B4 & 0.92 & 0.87 & - & 0.15 & - & 1.14 & 0.12 & 0.17 & - & 0.18 & - & 32.48 & 63.44 & 0.28 & 0.25 \\
\hline & B5 & 2.28 & 0.87 & 0.65 & 0.52 & 0.19 & 0.01 & 0.19 & 1.03 & - & 0.15 & - & 32.22 & 60.95 & 0.66 & 0.29 \\
\hline \multirow{2}{*}{ R1 } & R1.1 & 0.88 & 0.35 & 0.43 & 1.30 & 1.80 & - & - & - & - & - & - & 22.54 & 69.41 & 3.30 & - \\
\hline & R1.2 & 0.53 & 0.52 & 2.17 & 0.51 & 0.10 & - & - & - & - & - & - & 31.48 & 63.55 & 0.36 & 0.78 \\
\hline \multirow{3}{*}{ R2 } & R2.1 & 1.87 & 0.86 & - & 0.80 & 1.31 & 0.15 & 0.36 & - & - & - & - & 16.79 & 75.37 & 2.49 & - \\
\hline & $\mathrm{R} 2.2$ & 0.45 & 0.85 & - & 2.11 & 1.14 & 0.26 & - & 0.35 & - & - & - & 16.94 & 74.15 & 3.77 & - \\
\hline & $\mathrm{R} 2.3$ & 1.21 & 0.56 & - & 1.31 & 2.55 & 0.05 & 0.44 & 0.28 & - & - & - & 16.84 & 72.95 & 3.82 & - \\
\hline Y & Y & 0.28 & 2.58 & - & 2.61 & - & - & - & 0.33 & 0.42 & 0.10 & 0.37 & 19.11 & 70.60 & 3.60 & - \\
\hline $\mathrm{V}$ & $\mathrm{V}$ & 1.65 & 1.50 & - & 0.22 & - & 3.99 & 0.23 & - & - & - & - & 27.85 & 64.16 & - & 0.40 \\
\hline$S$ & S & 0.69 & 0.69 & - & 0.33 & - & 2.20 & 0.15 & - & - & - & - & 26.11 & 69.35 & 0.26 & 0.23 \\
\hline
\end{tabular}

In the case of the blue pigment, in addition to the homogeneous color sample (B0), five other samples were taken from different areas, containing the main color (B1-B5), with characteristics of easily differentiable surface structures, as follows: sample B1-an area unaffected by environmental factors, with slightly differentiated stratigraphy; sample B2-a central structure, homogeneous restricted area, used as a reference (low degree of contamination, with uniform nuance and stratigraphic structure); sample B3—surface structure fouled in varnish; samples B4 and B5-varnished, uncracked median structures.

Atomic percentage compositions of the six samples taken in the study (B0, B1-B5), correspond to the blue earth pigment, Ultramarine type, impurified more or less with other colors or with contamination materials, as follows: sample B0-Ultramarine blue, diluted in elaboration by mixing with Zinc white/Lithopone and/or Barium yellow, weakly impurified with chalk powder and gypsum, from the preparation (diffusion between application layers-archaeometric characteristic); samples B1 and B2-Ultramarine blue mixed with Zinc white, Chrome green, Lead red, Iron ocher and weakly impurified with chalk powder and gypsum, from the preparation and cardboard; sample B3-oxidative fouled varnish, diffused in the mass of the color of the Ultramarine blue and which has superficially embedded powders of atmospheric dust; sample B4 contains varnish of medium structure, weakly impurified with Ultramarine blue, diluted with Zinc white and Iron ocher (diffusion between pigments and the fouling structures-archaeometric feature); sample B5 contains varnish penetrated into the internal structure of the Ultramarine blue, mixed with Zinc white/Lithopone and Barium yellow/Iron ocher. 
The chemical difference between the two ultramarine pigments (blue and red) is found in the $\mathrm{Na}$ and $\mathrm{S}$ content $\left(\mathrm{Al}_{6} \mathrm{Na}_{8} \mathrm{O}_{24} \mathrm{~S}_{3} \mathrm{Si}_{6} / \mathrm{Al}_{6} \mathrm{Na}_{6} \mathrm{O}_{24} \mathrm{~S}_{8} \mathrm{Si}_{6}\right)$. The other elements $(\mathrm{Ca}, \mathrm{Ba}, \mathrm{Zn}, \mathrm{Fe}$, and $\mathrm{Cr}$ ) for these samples come from impurities originating from other pigments and fillers from the preparation, induced in the elaboration of the painting on the easel or directly on the support, respectively, from the atmospheric dust $(\mathrm{Si}, \mathrm{Al}, \mathrm{Mg}, \mathrm{Ca}, \mathrm{K}$, and $\mathrm{Cl}$ ) incorporated during the display or storage period.

For each color above, based on the percentage atomic composition and in correlation with the conservation state, a series of chemometric characteristics, with archaeometric value, were evaluated, given by the reports: $\mathrm{Si} / \mathrm{Al}, \mathrm{C} / \mathrm{O}, \mathrm{C} / \mathrm{S}, \mathrm{S} / \mathrm{O}, \mathrm{Zn} / \mathrm{O}, \mathrm{Zn} / \mathrm{C}$, and $\mathrm{Zn} / \mathrm{S}$.

Further, a similar discussion was made for the three other pictorial materials: two colors of red $(\mathrm{R} 1, \mathrm{R} 2)$ and one of yellow $(\mathrm{Y})$, then one for the uncontaminated varnish $(\mathrm{V})$ and one for the pressed cardboard support (S), without preparation.

In the case of the first color of red (R1), besides the area with homogeneous color (sample R1.1), an area containing color and varnish fouled on the surface was taken (sample R1.2), from which the archaeometric characteristics were identified (diffusion between application layers and diffusion between pigments and the fouling structures). The same chemometric ratios were then evaluated as for the colors of blue. If sample R1.1 has an internal structure unaffected by environmental factors, with legible stratigraphy, easily distinguishable, sample R1.2 has a superficial structure with fouled varnish. The elemental composition of the two colors: both R1.1 and R1.2 contain Ultramarine red pigment, mixed with Siena, Iron red and Zinc white/Lithopone and weakly impurified with chalk powder and gypsum, from preparation and cardboard, with the difference that R1.2 shows superficially areas with varnish fouling through oxidative processes.

For the second color of red (R2), three representative color areas were selected with superficial fouled varnish, one with uniform distribution (sample R2.1) and two with non-uniform distributions (samples R2.2 and R2.3), easy to differentiate with OM/SEM. The elemental compositions also correspond to Ultramarine red earth pigment, but differentiated: sample R2.1 contains Ultramarine red pigment covered with uniformly fouled varnish, mixed with Zinc white/Lithopone and weakly impurified with chalk powder and gypsum, from the preparation and cardboard, while the samples R2.2 and R2.3 have the same composition, but uneven fouling.

In the case of the yellow pigment, only one sample $(\mathrm{Y})$ was taken, in which the Chrome yellow pigment $\left(\mathrm{PbCrO}_{4}\right)$ and Lithopone (zinc sulphide mixed with barium sulphate), diluted with other colors (Ultramarine red and Iron ocher) were identified, and impurified with chalk powder and gypsum from the preparations, or with various contamination materials from the storage medium, having fouled varnish on the surface.

In the case of the varnish sample (V), based on the elemental composition, it corresponds to a varnish based on natural resins, oxidatively fouled, with the incorporation of atmospheric dust.

For the pressed cardboard support (S), similar to the varnish sample and the yellow one, only one sample was taken, and the SEM-EDX analysis was performed on the entire surface available for analysis. The elemental analysis corresponds to a cellulose material, impregnated with various leachable additives and filler material from the manufacturing processes and impurified by the materials in the missing layer.

The results obtained by SEM-EDX analysis are correlated with those by $\mu$-FTIR (Figure 17 and Table 2).

Following the $\mu$-FTIR analysis, the peak from $1730 \mathrm{~cm}^{-1}$ attributed to the carbonyl group and the $2936,2860,1458,1377$, and $1174 \mathrm{~cm}^{-1}$ peaks corresponding to the aliphatic groups were identified in all samples, highlighting the nature of the oil-based binder [10,26-28,31-34]. The presence of the peak in the spectrum a (preparation layer) suggests that the artist used oil, along with binder based on animal glue, according to some recipes that are still used today. Therefore, the oil did not migrate from the paint layer. 


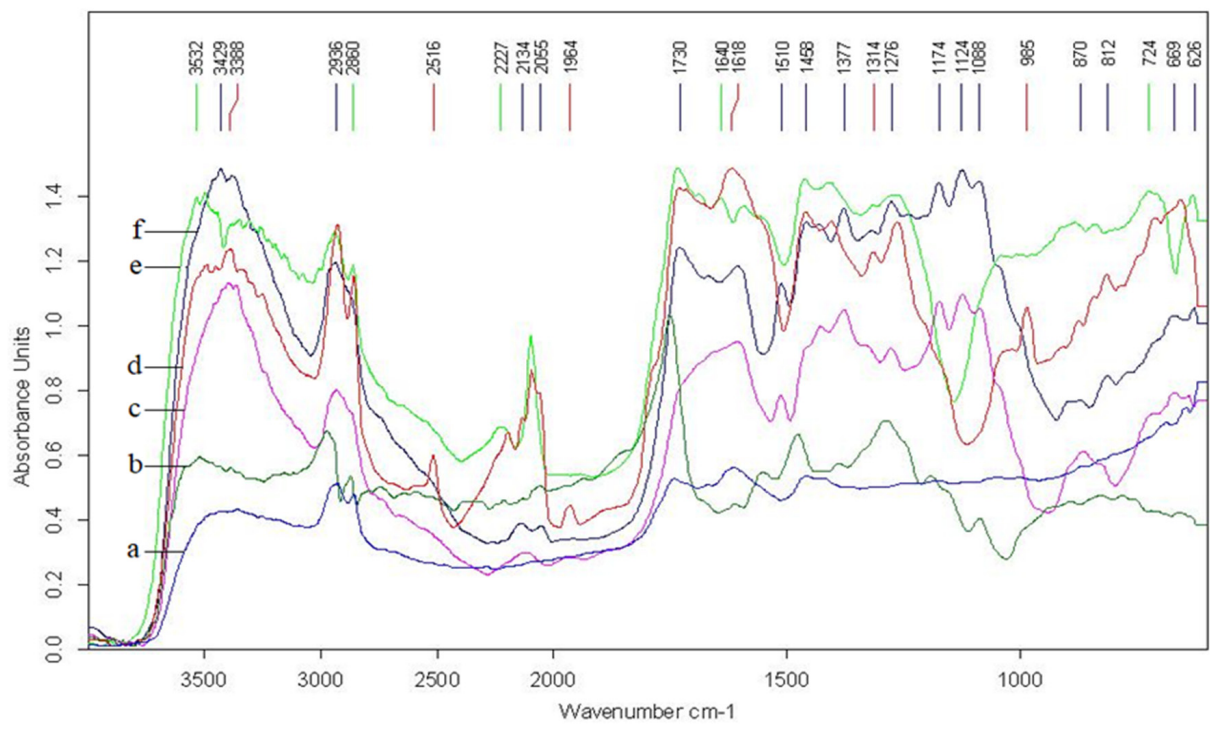

Figure 17. FT-IR spectrum for a series of samples analyzed by SEM-EDX: a-preparation layer (S), b-varnish (V), c-red (R), d-blue (B), e-yellow (Y), f-white (W).

Table 2. Representative peaks and spectral bands of the ions identified in the samples analyzed by micro-FTIR.

\begin{tabular}{|c|c|c|c|}
\hline Ion Type & $\begin{array}{l}\text { Expected Spectral } \\
\text { Bands }\left(\mathrm{cm}^{-1}\right)\end{array}$ & $\begin{array}{l}\text { Peak Present in } \\
\text { Samples }\left(\mathrm{cm}^{-1}\right)\end{array}$ & Samples Analyzed \\
\hline \multirow{2}{*}{ Silicate } & \multirow{2}{*}{$860-1175$} & $1174 ; 1088$ & $\mathrm{~V}$ \\
\hline & & $1174 ; 1124 ; 1088$ & $\mathrm{R}$ \\
\hline Aluminate & $800-920$ & 870 & $\mathrm{R}$ \\
\hline \multirow{2}{*}{ Sulphate and sulphide } & \multirow{2}{*}{$570-680 ; 960-1030$} & 985 & B \\
\hline & & 626 & $\mathrm{~W}$ \\
\hline \multirow{5}{*}{ Carbonate } & \multirow{5}{*}{$\begin{array}{c}670-745 ; 800-890 ; \\
1040-1100 ; 1320-1530\end{array}$} & 1458 & $\mathrm{~S}, \mathrm{~V}$ \\
\hline & & $1377 ; 1430 ; 1510$ & $\mathrm{R}$ \\
\hline & & $724 ; 812 ; 1458 ; 1400$ & B \\
\hline & & $724 ; 812$ & $\mathrm{Y}$ \\
\hline & & $\begin{array}{c}724 ; 812 ; 870 ; 1400 \\
1458\end{array}$ & W \\
\hline \multirow{3}{*}{ Phosphate } & \multirow{3}{*}{$\begin{array}{c}830-920 ; 1600-1900 ; \\
2150-2500 ; 2750-2900\end{array}$} & 2134 & $\mathrm{R}$ \\
\hline & & 2200 & $\mathrm{~B}$ \\
\hline & & 2227 & W \\
\hline $\mathrm{Pb}$ (II, III, IV) & $660-685$ & 669 & S, B \\
\hline \multirow{5}{*}{$\begin{array}{l}\text { Acvo- and } \\
\text { hidroxy-complexes, and } \\
\text { crystallized water }\end{array}$} & \multirow{5}{*}{$2850-4000$} & $2860 ; 2936 ; 3429$ & S \\
\hline & & $2860 ; 2936 ; 3532$ & $\mathrm{~V}$ \\
\hline & & $2936 ; 3388$ & $\mathrm{R}$ \\
\hline & & $2860 ; 2936 ; 3388$ & B \\
\hline & & $2860 ; 2936 ; 3388 ; 3429$ & W \\
\hline \multirow{3}{*}{$\begin{array}{l}\text { Binder (amide I and } \\
\text { amide II) }\end{array}$} & \multirow{3}{*}{$\begin{array}{c}\approx 1547 ; \\
1610-1690\end{array}$} & 1540 & $\mathrm{~V}$ \\
\hline & & 1618 & S, R, B \\
\hline & & $1618 ; 1640$ & W \\
\hline \multirow{5}{*}{ Varnish (ester groups) } & \multirow{5}{*}{$\begin{array}{l}\approx 1265 \\
\approx 1750\end{array}$} & 1730 & $S$ \\
\hline & & $1730 ; 1276$ & $\mathrm{~V}$ \\
\hline & & 1276 & $\mathrm{R}$ \\
\hline & & $1730 ; 1276$ & B \\
\hline & & $1730 ; 1276$ & W \\
\hline
\end{tabular}


The bands characteristic of amide I and II with the peaks from 1640 and $1618 \mathrm{~cm}^{-1}$ indicate the presence of protein binder based on animal glue. It is expected to have the presence of peak from $1550 \mathrm{~cm}^{-1}$, which belongs to amide II in animal glue. It is shifted to $1540-1510 \mathrm{~cm}^{-1}$, because the bone glue binder, obtained by hydrothermal processes, certainly affected the primary protein, which underwent degradation changes by chemically breaking down into oligo-peptides. Moreover, complexation interactions with transition metals in the composition of pigments have led to other composition changes.

Additionally, the presence in small quantities of some mineral salts ( $\mathrm{Zn}, \mathrm{Pb}, \mathrm{Ca}$, etc.) in the form of carboxylate (metal soaps), proves that the painter masters the artistic technique.

The preparation layer (Figure 17a) shows the peaks: 3429, 2936, 2860, 1730, 1618, 1458, and $669 \mathrm{~cm}^{-1}$ characteristic of the binder based on animal glue and carbonate.

The varnish (Figure 17b) shows the peaks 3532, 2936, 2860, 1730, 1540, 1458, 1276, 1174, and $1088 \mathrm{~cm}^{-1}$ characteristic of boiled linseed oil-based binder [10,26-30].

The red pigment (Figure 17c) shows the peaks 3388, 2936, 2134, 1618, 1510, 1430, 1377, 1276, 1174, 1124,1088 , and $870 \mathrm{~cm}^{-1}$ characteristic of the binder and the mixture of Ultramarine red, Sienna and Iron red, from the elaboration on the easel, together with white from calcium and barium carbonate impurified in the technology of manufacturing the oil color.

The blue pigment (Figure 17d) shows the peaks 3388, 2936, 2860, 2516, 2200, 2055, 1964, 1730, 1618, $1458,1400,1314,1276,985,812,724,669 \mathrm{~cm}^{-1}$ characteristic of the binder, Ultramarine blue and Zinc white $[10,26-28,31-35]$.

The yellow pigment (Figure 17e) in addition to the binder peaks has the 724 and $812 \mathrm{~cm}^{-1}$ peaks characteristic of Lithopone [10,26-28,31-34,36].

The white pigment (Figure 17f) shows the peaks 3429, 3388, 2936, 2860, 2227, 2055, 1730, $1640,1618,1458,1400,1276,870,812,724,626 \mathrm{~cm}^{-1}$ characteristic of the binder and the white zinc $[10,26-28,31-34,37]$.

For the varnish, pictorial materials and support samples, representative areas were selected in the SEM images (Figure 16), which, in conjunction with their elemental EDX analysis (Table 1), allowed the evaluation of archaeometric characteristics, such as the porosity gradient of the varnish, colors and preparation, the degree of penetration of the colors in the varnish and of the varnish/colors by the oxidatively fouled superficial structures, and the chemometric ones, respectively: elemental stoichiometry reports: $\mathrm{Si} / \mathrm{Al}, \mathrm{C} / \mathrm{O}, \mathrm{C} / \mathrm{S}, \mathrm{S} / \mathrm{O}, \mathrm{Zn} / \mathrm{O}, \mathrm{Zn} / \mathrm{C}$, and $\mathrm{Zn} / \mathrm{S}$ (Table 3), which allowed the estimation of the period of the painting elaboration around 1890.

The data in Table 3 show a good correlation between the two archaeometric characteristics highlighted in the W4 samples ( $250 \mu \mathrm{m}$ for the gradient of the porosity of the colors and varnish, respectively, the degree of penetration of the colors in the varnish and of the fouled structures from the surface in the volume phase for the white colors, $130-260 \mu \mathrm{m}$ to blue, 50-130 $\mu \mathrm{m}$ to red and yellow) and W5 (150 $\mu \mathrm{m}$ depth of penetration of oxidatively fouled superficial structures, to white; $50-130 \mu \mathrm{m}$ to blue, red, and yellow).

The two archaeometric characteristics correspond to a range of about 130 years (in white the rate is about 1.0-2.0 $\mu \mathrm{m} /$ year; in blue $0.2-2.0 \mu \mathrm{m} /$ year; in red and yellow $0.5-1.0 \mu \mathrm{m} /$ year; in varnish $0.2-0.5 \mu \mathrm{m} /$ year), considering the constant storage conditions.

Regarding the chemometric characteristics (columns 1-7 of Table 3), the evaluation is based on the stoichiometric ratio of the basic congruent, from the composition of the pictorial materials, namely: $\mathrm{Si} / \mathrm{Al}$ (the caustic modulus of the earth colors), which varies between 0.589 and $1.084 ; \mathrm{C} / \mathrm{O}$ (of $\mathrm{CO}_{3}{ }^{2-}$ ion) is $0.25 ; \mathrm{S} / \mathrm{O}$ (of $\mathrm{SO}_{4}{ }^{2-}$ ion) is 0.5 and $\mathrm{Zn} / \mathrm{O}$ (of zinc white- $\mathrm{ZnO}$ ) is 4.063 .

The seven chemometric characteristics of the colors in Table 3 represent the deviations from these four stoichiometric ratios, due to oxidative processes in superficial structures or dilution by exogenous contamination with aluminate, silicate, carbonate, and sulphate anions, which occur during display or storage without display. As for the $\mathrm{C} / \mathrm{S}, \mathrm{Zn} / \mathrm{C}$, and $\mathrm{Zn} / \mathrm{S}$ ratios, only the first one, which corresponds to the ratio between carbonate and sulfate anions, has a wide range of variation, which allows to evaluate 
the degree of mixing between colors when elaborating (enacting), and the others provide information on the degree of carbonation and the degree of sulfation that occur over time. These represent reports resulting from oxidative processes and impurification processes with anions from acid-basic and complexation processes.

Table 3. Evaluation of chemometric characteristics, with archaeometric function.

\begin{tabular}{|c|c|c|c|c|c|c|c|c|}
\hline \multirow{2}{*}{\multicolumn{2}{|c|}{$\begin{array}{c}\text { Sample/ } \\
\text { Area }\end{array}$}} & \multicolumn{7}{|c|}{ Chemometric Characteristic } \\
\hline & & Si/Al & $\mathrm{C} / \mathrm{O}$ & $\mathrm{C} / \mathrm{S}$ & $\mathrm{S} / \mathrm{O}$ & $\mathrm{Zn} / \mathrm{O}$ & $\mathrm{Zn} / \mathrm{C}$ & $\mathrm{Zn} / \mathrm{S}$ \\
\hline \multirow{5}{*}{ W } & W1 & - & 0.342 & 71.172 & 0.005 & 0.303 & 0.886 & 63.034 \\
\hline & W2 & - & 0.278 & 18.839 & 0.015 & 0.396 & 1.424 & 26.828 \\
\hline & W3 & - & 0.408 & 38.967 & 0.010 & 0.320 & 0.785 & 30.600 \\
\hline & W4 & - & - & - & 0.007 & 0.461 & - & 67.935 \\
\hline & W5 & 1.212 & 0.159 & 1.472 & 0.108 & 0.041 & 0.255 & 0.375 \\
\hline \multirow{6}{*}{ B } & B0 & 1.176 & 0.150 & 1.481 & 0.101 & 0.008 & 0.053 & 0.078 \\
\hline & B1 & 0.139 & 0.324 & 4.568 & 0.071 & 0.022 & 0.069 & 0.315 \\
\hline & B2 & 0.074 & 0.267 & 3.349 & 0.080 & 0.106 & 0.397 & 1.331 \\
\hline & B3 & 1.283 & 0.525 & 68.043 & 0.008 & - & - & - \\
\hline & B4 & 1.057 & 0.512 & 116.000 & 0.004 & 0.003 & 0.005 & 0.607 \\
\hline & B5 & 2.621 & 0.529 & 48.818 & 0.011 & 0.017 & 0.032 & 1.561 \\
\hline \multirow{2}{*}{ R1 } & R1.1 & 2.514 & 0.325 & 6.830 & 0.048 & - & - & - \\
\hline & R1.2 & 1.019 & 0.495 & 87.444 & 0.006 & - & - & - \\
\hline \multirow{3}{*}{ R2 } & $\mathrm{R} 2.1$ & 2.174 & 0.223 & 6.743 & 0.033 & - & - & - \\
\hline & $\mathrm{R} 2.2$ & 0.529 & 0.228 & 4.493 & 0.051 & 0.005 & 0.021 & 0.093 \\
\hline & $\mathrm{R} 2.3$ & 2.161 & 0.231 & 4.408 & 0.052 & 0.004 & 0.017 & 0.073 \\
\hline Y & $\mathrm{Y}$ & 0.109 & 0.271 & 5.308 & 0.051 & 0.005 & 0.017 & 0.092 \\
\hline $\mathrm{V}$ & $\mathrm{V}$ & 1.100 & 0.434 & - & - & - & - & - \\
\hline$S$ & $S$ & 1.000 & 0.376 & 100.423 & 0.004 & - & - & - \\
\hline
\end{tabular}

The first definite chemometric characteristic related to the increase of the porosity due to the fragility of the binder and the penetration of $\mathrm{CO}_{2}$, respectively, of $\mathrm{SO}_{2}$ in the presence of hygroscopic humidity (sequential processes of carbonation and sulfation), are given by the $\mathrm{C} / \mathrm{S}$ and $\mathrm{Zn} / \mathrm{C}$ ratios.

The C/S ratio increases compared with the reference sample (W2), for the white samples between 0.08 (W5) and 3.8 (W1) times; in the blue ones, between 2.26 (B2) and 78.4 (B4) times, in the red ones between 1.00 and 1.50 times, and for yellow 5.3 times. These values correspond to deviations for about 130 years old.

Instead, the second chemometric characteristic related only to the degree of carbonation ( $\mathrm{Zn} / \mathrm{C}$ ratio), for the same colors, varies: between 0.014 (W5) and 2.4 (W1 and W4) for white; between 0.1 (B4) and 7.5 (B2) in blue; between 0.17 (R2.3) and 0.021 (R2.2) in red and between 0.017 and 0.02 in yellow.

Of the four colors evaluated chemometrically from the SEM-EDX analysis data, only white is the most strongly influenced in time by the factors and agents in the storage environment, having a weak basic and inert redox character, susceptible to carbonation and sulfation hydration processes, while the other colors give both carbonation and sulfation processes, but also redox and complexation processes, the first of these being very weak.

For all four colors, the evolution rate of the chemometric characteristics corresponds to an age of about 130 years, having special value in archaeometric evaluations. 
For the pressed cardboard support (S), there is also a good correlation between the archaeometric characteristics (the fragility of cellulose fibers and the binder) and the chemometric ones (the thickness of the fouled surface structures, between 100 and $300 \mu \mathrm{m}$ ). The two characteristics correspond to an interval of about 130 years, based on the evolution over time of the $\mathrm{Al} / \mathrm{Si}$ and $\mathrm{C} / \mathrm{O}$ modules.

\section{Conclusions}

Based on the data obtained, the following conclusions are presented:

- The painting is made by Nicolae Grigorescu, in 1886-1888 period, and corresponds to the age of the painting materials and the support. The framing system and the re-varnishing intervention are subsequent to the artwork's elaboration.

- The painting has an insignificant lack of pictorial material and extended ageing cracks are visible only in small areas of white flower petals;

- The pictorial materials were identified by EDX and $\mu$-FTIR, and in the analysis the most representative oil colors were white, blue, red, and yellow, together with the cardboard support;

- It was established by static and dynamic reflectography in different light sources (visible, white-green, UV, and IR) and by graphoscopy, that the painter's signature and Amelia Pavel's authentication writing, are original;

- The authentication of the painting was done by determining the evolution of archaeometric and chemometric characteristics, with archaeometric value, identified in SEM microphotographs and from data obtained by EDX and $\mu$-FTIR, following the surface and cross-section analysis of some representative micro-samples of pictorial materials and support;

- Among the archaeometric (evolutionary) characteristics from SEM microphotographs, analyzed in cross section for the fractal area, two allowed the evaluation of the painting's age, namely: the gradient of the porosity of the pictorial layers and of the varnish, respectively, the degree of the penetration of the pigments in the varnish and of the oxidatively fouled dirt from the surface in the volume phase of the pictorial materials, as being of $250 \mu \mathrm{m}$ for the white pigments, $130-260 \mu \mathrm{m}$ for blue, 50-130 $\mu \mathrm{m}$ for red and yellow, and corresponding to an interval of about 130 years (in white the rate is approx. 1.0-2.0 $\mu \mathrm{m} /$ year, blue $0.2-2.0 \mu \mathrm{m} /$ year, red and yellow $0.5-1.0 \mu \mathrm{m} /$ year, varnish $0.2-0.5 \mu \mathrm{m} /$ year), considering the constant display conditions in the gallery;

- Regarding the chemometric characteristics, the evaluation was made starting from the stoichiometric ratio of the basic congruents, found in the composition of the pictorial materials, namely: $\mathrm{Si} / \mathrm{Al}$ (caustic modulus of earth colors), which varies between 0.589 and $1.084 ; \mathrm{C} / \mathrm{O}$ (of $\mathrm{CO}_{3}{ }^{2-}$ ion) approx. $0.25 ; \mathrm{S} / \mathrm{O}$ (of the $\mathrm{SO}_{4}{ }^{2-}$ ion) approx. 0.5 and $\mathrm{Zn} / \mathrm{O}$ approx. 4.063;

- Among the chemometric characteristics: $C / S, Z n / C$, and $Z n / S$, only the first, which corresponds to the ratio between carbonate and sulfate anions, has a wide range of variation, which allows only the assessment of the degree of mixing between colors when elaborating the work of art, while the others provide information about the degree of carbonation and sulfation, which take place over time, having a good coherence in archaeometric analysis.

- For all four pictorial materials, varnish, and support, the rate of evolution of chemometric characteristics corresponds to an age of about 130 years.

Author Contributions: Conceptualization and project administration P.O.T., methodology and supervision I.S., investigation and data curation V.V., methodology and investigation I.G.S., formal analysis and investigation I.C.N., writing-review and editing and validation A.V.S. All authors have read and agreed to the published version of the manuscript.

Funding: This research received no external funding.

Conflicts of Interest: The authors declare no conflict of interest. 


\section{References}

1. Sandu, I.; Sandu, I.C.A.; van Saanen, A. Scientific Expertise of Works of Art; Al.I.Cuza University Publishing House: Iasi, Romania, 1998; Volume I.

2. Sandu, I.; Sandu, I.C.A.; Sandu, I.G. Colorimetry in Art; Corson: Iaşi, Romania, 2002.

3. Sandu, I. Degradation and Deterioration of Cultural Heritage Assets; Al.I.Cuza University Publishing House: Iasi, Romania, 2008; Volume I.

4. Sandu, I. Degradation and Deterioration of Cultural Heritage Assets; Al.I.Cuza University Publishing House: Iasi, Romania, 2008; Volume II.

5. Sandu, I.; Tanasa, P.O.; Sandu, I.C.A.; Negru, I.C.; Sandu, A.V.; Vasilache, V. Authentication of an Old Violin by Multianalytical Methods. Appl. Sci. Basel 2020, 10, 306. [CrossRef]

6. Sandu, I.; Iurcovschi, C.T.; Sandu, I.G.; Vasilache, V.; Negru, I.C.; Brebu, M.; Ursu, P.S.; Pelin, V. Multianalytical Study for Establishing the Historical Contexts of the Church of the Holy Archangels from Cicau, Alba County, Romania, for its Promotion as a World Heritage Good I. Assessing the preservation-restoration works from the 18th century. Rev. Chim. 2019, 70, 2538-2544. [CrossRef]

7. Sandu, I.C.A.; Bracci, S.; Sandu, I.; Loberfaro, M. Integrated analytical study for authentication of five russian icons (XVII-XVIII Century). Microsc. Res. Tech. 2009, 72, 755-765. [CrossRef] [PubMed]

8. Sandu, I.C.A.; Luca, C.; Sandu, I.; Vasilache, V.; Hayashi, M. Authentication of ancient easel-paintings through materials identification from polychrome layers. III. Cross-section and staning analysis. Rev. Chim. 2008, 59, 855-866. [CrossRef]

9. Sandu, I.C.A.; Luca, C.; Sandu, I.; Vasilache, V.; Hayashi, M. Authentication of the ancient easel paintings through materials identification from the polychrome layers-II. Analysis by means of the FT-IR spectrophotometry. Rev. Chim. 2008, 59, 384-387. [CrossRef]

10. Rusu, R.D.; Simionescu, B.; Oancea, A.V.; Geba, M.; Stratulat, L.; Salajan, D.; Ursu, L.E.; Popescu, M.C.; Dobromir, M.; Murariu, M.; et al. Analysis and structural characterization of pigments and materials used in Nicolae Grigorescu heritage paintings. Spectrochim. Acta Part. A Mol. Biomol. Spectrosc. 2016, 168, $218-229$. [CrossRef]

11. Sandu, I.C.A.; Bracci, S.; Sandu, I. Instrumental analyses used in the authentication of old paintings I. Comparison between two Icons of XIXth Century. Rev. Chim. 2006, 57, 796-803.

12. Spiridon, P.; Sandu, I.C.A.; Nica, L.; Iurcovschi, C.T.; Colbu, D.E.; Negru, I.C.; Vasilache, V.; Cristache, R.A.; Sandu, I. Archaeometric and Chemometric Studies Involved in the Authentication of Old Heritage Artefacts II. Old linden and poplar wood put into work. Rev. Chim. 2017, 68, 2422-2430. [CrossRef]

13. Spiridon, P.; Sandu, I.C.A.; Nica, L.; Vasilache, V.; Sandu, I. Archaeometric and Chemometric Studies Involved in the Authentication of Old Heritage Artefacts I. Contributions of the Iasi school of Conservation Science. Rev. Chim. 2017, 68, 2018-2027. [CrossRef]

14. Baker, P. Protecting Art, Protecting Artists and Protecting Consumers Conference; Autralian Institute of Criminology: Sydney, Australia, 1999.

15. Matei, G. Investigarea Criminalisticã a Infractiunilor Privind Operele de Artã si Artefactele Arheologice; Universul Juridic: Bucharest, Romania, 2010.

16. Sandu, I.; Cotiuga, V. Cercetarea Bunurilor de Patrimoniu si a Documentelor Falsificate; AIT Laboratory: Bucharest, Romania, 2011.

17. Marcu, G. (Coord.) Encyclopedia of Women's Personalities in Romania; Meronia: Bucharest, Romania, 2012.

18. Available online: http://enciclopediaromaniei.ro/wiki/Amelia_Pavel/ (accessed on 3 March 2020).

19. Available online: https://g1b2i3.wordpress.com/alexandru-ciucurencu-pictor-roman/nicolae-grigorescu15mai-1838-pitaru-dambovita-21-iulie-1907-campina-i/nicolae-grigorescu-ramura-de-mar-inflorit// (accessed on 3 March 2020).

20. Sandu, I. Aspecte Moderne Privind Conservarea Patrimoniului Cultural, vol.V. Identificarea Materialelor Picturale; Performantica: Iasi, Romania, 2007.

21. Negru, I.C.; Vasilache, V.; Sandu, I.; Olariu, R.I.; Tanasa, P.O.; Potolinca, D.; Sandu, I.C.A. Depth Profiling of Diffraction-based Security Features in Authentic and Counterfeit Banknotes. Mater. Plast. 2017, 54, 321-325. [CrossRef]

22. Potolinca, D.; Negru, I.C.; Vasilache, V.; Arsene, C.; Paduraru, M.; Sandu, I. Forensic Expertise of the Paper Support of Counterfeit Documents. Mater. Plast. 2017, 54, 186-189. [CrossRef] 
23. Sandu, I.; Luca, C.; Sandu, I.C.A.; Vasilache, V. Authentication of ancient easel-paintings through materials identification from polychrome layers. I. Gaschromatography analysis. Rev. Chim. 2007, 58, 879-886.

24. Cristache, R.A.; Sandu, I.C.A.; Simionescu, A.E.; Vasilache, V.; Budu, A.M.; Sandu, I. Multi-analytical Study of the Paint Layers Used in Authentication of Icon from XIXth Century. Rev. Chim. 2015, 66, 1034-1037.

25. Kuckova, S.; Sandu, I.C.A.; Crhova, M.; Hynek, R.; Fogas, I.; Muralha, V.S.; Sandu, A.V. Complementary cross-section based protocol of investigation of polychrome samples of a 16th century Moravian Sculpture by optical, vibrational and mass spectrometric techniques. Microchem. J. 2013, 110, 538-544. [CrossRef]

26. Geba, M.; Stratulat, L.; Vornicu, N.; Salajan, D.; Manea, M.M. Research on the Chromatic Palette of a Modern Romanian Painter. Rev. Chim. 2017, 68, 447-452. [CrossRef]

27. D-Vasilescu, E.E. Twentieth Century Developments in European Icon Painting. Ikon J. Iconogr. Stud. 2016, 9, 335-342. [CrossRef]

28. Geba, M.; Malutan, T.; Malutan, C.; Stratulat, L.; Salajan, D.; Iutis, M.; Drutu, V.; Chirita, L. Environmental care for Romanian oil paintings. technical examination of degradation phenomena in canvas textiles. Environ. Eng. Manag. J. 2017, 16, 725-729.

29. Sandu, I.C.A.; Roque, A.C.A.; Matteini, P.; Schafer, S.; Agati, G.; Correia, C.R.; Viana, J.F.F.P. Fluorescence recognition of proteinaceous binders in works of art by a novel integrated system of investigation. Microsc. Res. Tech. 2012, 75, 316-324. [CrossRef]

30. Bratu, I.; Moldovan, Z.; Kacso, I.; Marutoiu, C.; Trosan, L.; Marutoiu, V.C. A Transylvanian Diptych Wooden Icon: Wooden Support and Painting Materials Investigations. Rev. Chim. 2013, 64, 524-528.

31. Cristache, R.A.; Sandu, I.C.A.; Budu, A.M.; Vasilache, V.; Sandu, I. Multi-analytical Study of an Ancient Icon on Wooden Panel. Rev. Chim. 2015, 66, 348-352.

32. Sandu, I.C.A.; Luca, C.; Sandu, I.; Pohontu, M. Research regarding the soft wood support degradation evaluation in old paintings, using preparation layers. II. IR and FTIR Spectroscopy. Rev. Chim. 2001, 52, 409-419.

33. Sandu, I.C.A.; Murta, E.; Ferreira, S.; Pereira, M.F.C.; Kuckova, S.H.; Valbi, V.; Dias, L.; Prazeres, C.; Cardoso, A.M.; Mirao, J.; et al. A comparative multi-technique investigation on material identification of gilding layers and the conservation state of 7 portuguese mannerist altarpieces. Int. J. Conserv. Sci. 2015, 6, 439-454.

34. Van der Weerd, J.; van Loon, A.; Boon, J.J. FTIR Studies of the Effects of Pigments on the Aging of Oil. Stud. Conserv. 2005, 50, 3-22. [CrossRef]

35. Available online: http://lisa.chem.ut.ee/IR_spectra/oil_color/ (accessed on 3 March 2020).

36. Available online: http://lisa.chem.ut.ee/IR_spectra/oil_color/lithopone-linseed-oil/(accessed on 3 March 2020).

37. Available online: http://lisa.chem.ut.ee/IR_spectra/oil_color/zinc-white-linseed-oil/ (accessed on 3 March 2020). 